\title{
Examining the Impact of Air Passenger Transport on International Long-Distance Regular Bus Transport in the Slovak Republic
}

\author{
Jozef Gnap ${ }^{1, *}$, Tomáš Settey ${ }^{1}$, and Dominika Beňová ${ }^{1}$ \\ ${ }^{1}$ University of Žilina, Faculty of Operation and Economics of Transport and Communications, \\ Department of Road and Urban Transport, Univerzitná 8215/1, 01026 Žilina, Slovakia
}

\begin{abstract}
The paper deals with the study of the impact of regular air passenger transport on international long-distance regular bus transport in the Slovak Republic. The comparative period is 2017 (2018) with 2008. The issue is also related to the issue of the use of Slovakian airports for regular air transport after the Slovak Republic entered the European Union in 2004. According to the results of the 2008 survey, both modes of transport have significantly affected the economic crisis. The development of low-cost airlines also affected the decrease in the number of issued transport licenses in 2018 compared to 2008 in international regular bus transport.
\end{abstract}

\section{Introduction}

The importance of air traffic for increasing the mobility of the population of the served regions is undeniable. Regular air transport is important for industry, logistics, but also for the development of regions in terms of tourism. Road freight transport generally increases with GDP growth $[1,2]$. The development of demand for public transport is influenced by a number of determinants, including the quality of transport services [3, 4]. Road transport, including bus transport, is generally more burdened by charges and taxes in relation to the internalisation of external costs than other modes of transport [4-7]. This can affect the development of costs and hence the price of regular bus services. In regular air transport, particularly within Europe, the liberalization of the transport market has increased the number of airlines and the creation of low-cost airlines, which after the accession of the Slovak Republic to the EU affected also the Slovak Republic. From the point of view of low cost airlines, the costs of specific airports are very important [8].

Similarly, after the accession of the Slovak Republic to the EU (since 1 May 2004), competition on the regular long-distance bus transport market has increased, following the acquisition of a Community license after meeting the conditions. This has caused the impact of development of regular air transport to regular long-distance bus transport and, in particular, international public bus transport in the Slovak Republic; is the research theme of the submitted contribution.

\footnotetext{
Corresponding author: jozef.gnap@fpedas.uniza.sk
} 


\section{Development of regular international bus transport from the Slovak Republic}

The Slovak Republic was founded on January 1, 1993 by the dividing of the former Czechoslovakia. While in 1993 there were only 68 regular international lines starting in the Slovak Republic so in 2008 it was already 159 lines. From this number in 1993 to 33 lines to the Czech Republic, i.e. 48,52 \%. Until the EU Member States were 17 bus lines and 18 lines were a.k.a. in the so- third countries outside the EU.

Slovak Republic joined the European Union 1.5.2004. In the year 2008, the Slovak Republic has been in the EU for four years and the economic crisis has only come in the fourth quarter. Of the above number of lines in 2008, up to 142 lines was to the EU Member States still account for up to 75 bus lines in the Czech Republic, i.e. $47.16 \%$. Here is an obvious demand for transports to EU Member States because only 17 bus lines were in the so-called third countries outside the EU, i.e. 10,69\%. The comparison shows that the number of bus lines grew, but the percentage ratio to the Czech Republic remained the almost preserved decrease by only $1.36 \%$.

In tab. 1 is the comparison of issued licenses for international regular bus transport from the Slovak Republic in 2008 and in 2018 (September). As a basis, licenses were not taken for the bus line because the lines have different tracing and are not always operated. It should also be noted that in tab. 1 are not bus lines that start outside the territory of the Slovak Republic but pass through the territory of the SR.

Table 1. Comparison of licenses issued for international regular bus transport from the Slovak Republic in 2008 and in 2018; Source: authors based on data from MDV SR

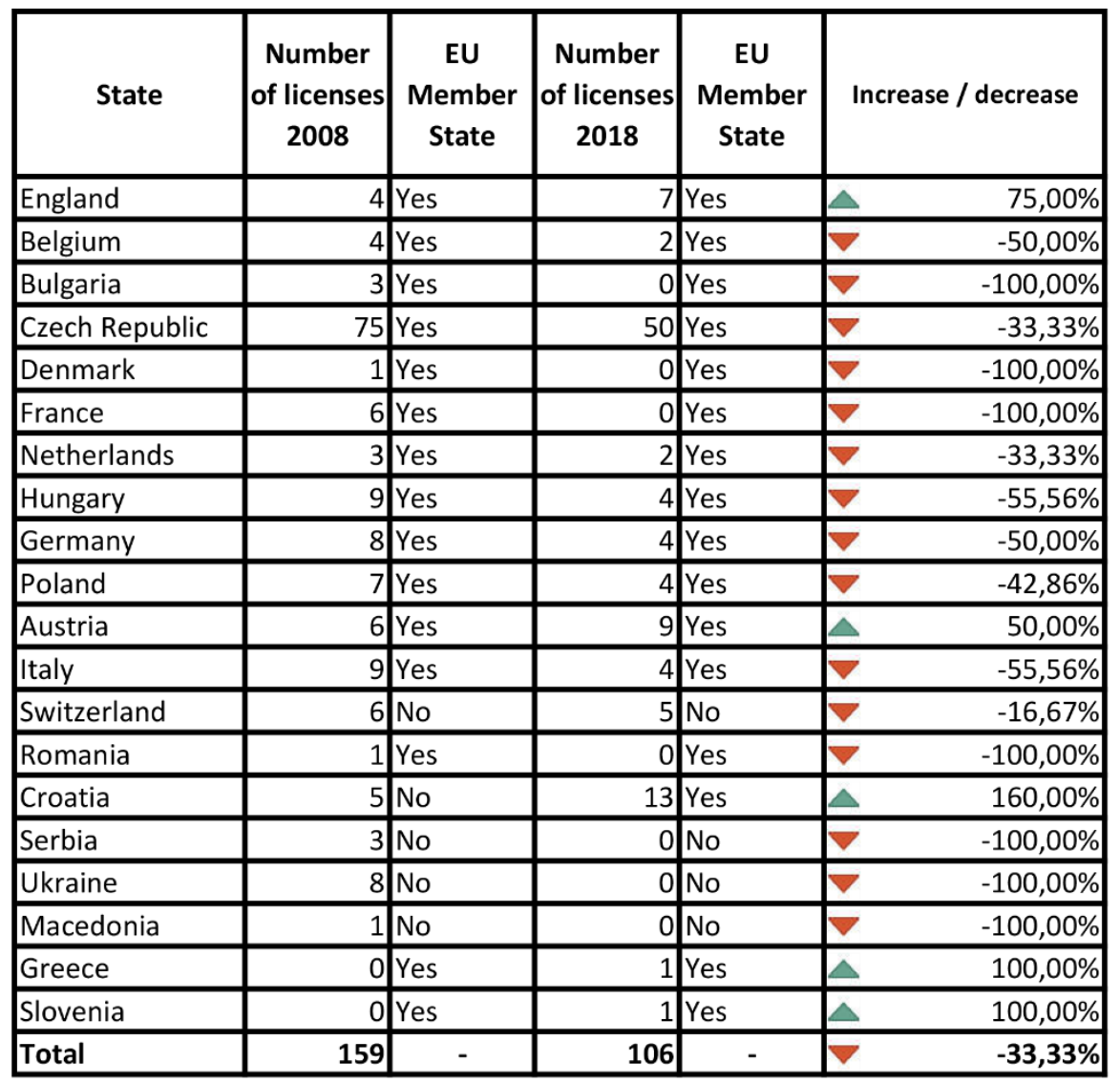


In terms of comparing the number of licenses to operate regular international bus services between 2008 and 2018, we can see a decrease in the number of licenses by up to $33.33 \%$. Only England and Austria destinations recorded an increase in the number of licenses. Two new destinations have been added, namely Greece and Slovenia. On the other hand, from the beginning in the SR aren't operating bus lines to Romania, Serbia, Ukraine, Macedonia, Denmark, France and Bulgaria.

So, in terms of international regular bus services, its supply declined between 2008 and 2018.

\section{Development in regular air transport in the Slovak Republic}

In Slovakia were established a total of 98 civilian airports in 2008. 14 of them have public airport status, 12 non-public airport status ( 20 of which are used only for sport flying) and 72 serve as an agricultural airport.

In 2004, it was in compliance with Act no. 136/2004 Coll. Airport Transfers performed by airport companies. Joint stock companies were founded of M. R. Stefanik - Airport Bratislava, a.s. (BTS) and Kosice Airport - Airport Kosice, a.s. with 100\% ownership of the state. A part of the property these joint stock companies became a.k.a. the infrastructure assets (take-off and landing tracks or runway, taxiway and apron for aircraft). Later, with the privatization of the owner, the structure of Airport Kosice, a.s., changed, and in the case of M. R. Stefanik Airport, a.s., the owner structure was modified in the following ratio - 34 $\%$ shares owned by the State through the Ministry of Transport and Construction of the Slovak Republic and $66 \%$ National Property Fund.

In 2005, within the meaning of the same law, joint stock companies were founded with a mixed ownership structure of the state and local authorities - Airport Poprad -Tatry, a.s., Airport Company Zilina, a.s., Airport Sliac, a.s. and Airport Piestany, a.s. At these airports (except Sliac airport), the infrastructure assets did not become the property of the airport companies, but they were acquired by the higher territorial units (VUC) by free transfer. Subsequently, the VUC rented this basic equipment the airport to airport companies for 1, $\operatorname{SKK}(0,03$ euros) for a period of 20 years [9].

At present, 2018 (September) is a regular air passenger transport conducted in Slovakia only from Bratislava, Kosice and Poprad-Tatry airports. In August 2012, scheduled air services from Zilina to Prague were cancelled.

According to the general assumptions given in the materials „Concept of air transport development of the Slovak Republic for the period up to 2010"and on the basis analysis of airport, air traffic in Slovakia by 2010 should be grow in the range of 10\% (pessimistic assumption) $-23 \%$ (optimistic assumption) - see Figure 1. On the basis of this and further consultations with expert advisers and institutions, Bratislava Airport Management has prepared an updated expected development of traffic at M. R. Stefanik Bratislava Airport for the period 2007 to 2019 [10].

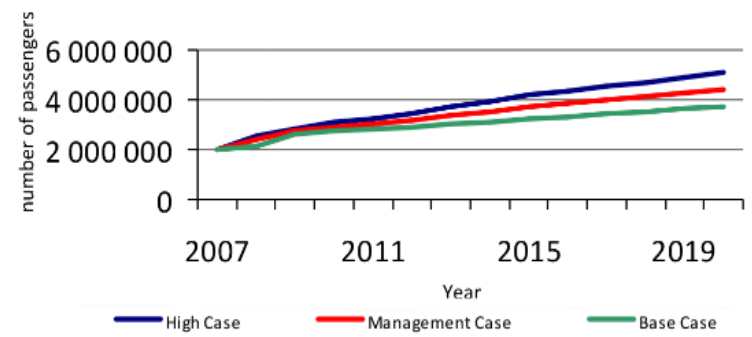

Fig. 1 Estimated development of transport volume at M. R. Stefanik Airport Bratislava for the period up to 2020; Source: [10] 
This predicted development has not been fulfilled. In 2017, the Airport M.R. Stefanik Bratislava equipped both in regular and irregular air transport in total 1,942 mil. of passengers (Table 2).

Due to the focus of the research on the impact of the development of regular air passenger transport on international long-distance regular bus transport in the Slovak Republic, we analyze the development of regular air transport.

Table 2. Development of equipped passengers in regular air transport for the years 2007 to 2017 M.R. Stefanik Bratislava; Source: authors based on data from [11]

\begin{tabular}{|c|c|c|c|c|c|c|c|c|c|c|c|}
\hline \begin{tabular}{|l|} 
Year \\
\end{tabular} & 2007 & 2008 & 2009 & 2010 & 2011 & 2012 & 2013 & 2014 & 2015 & 2016 & 2017 \\
\hline Regular traffic & 1611211 & 1753752 & 1305505 & 1233300 & 1122907 & 971009 & 919730 & 875322 & 1074700 & 1335007 & 1373634 \\
\hline $\begin{array}{l}\text { Year-to-year } \\
\text { development }\end{array}$ & & $8,85 \%$ & $-25,56 \%$ & $-5,53 \%$ & $-8,95 \%$ & $-13,53 \%$ & $-5,28 \%$ & $-4,83 \%$ & $22,78 \%$ & $24,22 \%$ & $2,89 \%$ \\
\hline $\begin{array}{l}\text { Development } \\
\text { compared to } 2014\end{array}$ & & & $49,15 \%$ & $40,90 \%$ & $28,29 \%$ & $10,93 \%$ & $5,07 \%$ & & $22,78 \%$ & $52,52 \%$ & $56,93 \%$ \\
\hline
\end{tabular}
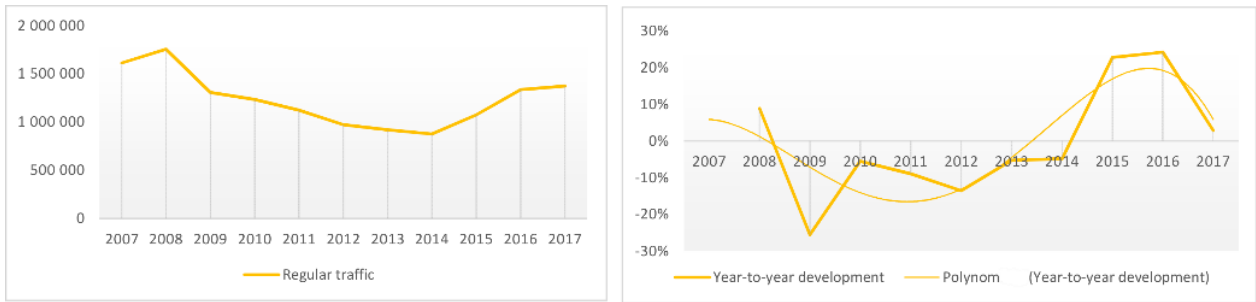

Fig. 2 Development of the number of passengers in regular air transport (left); trend of the year-onyear development of the number of passengers in regular air transport at the M R. Stefanik Bratislava Airport for the period 2007-2017 (right); Source: authors based on data from [12].

The number of passengers after the economic crisis, which began in September 2008 and continued from 2009 to 2014 and others, the number of passengers in the regular air transport at Bratislava Airport was decreasing and from 2015 again started to increase but still did not reach the number of passengers before this crisis.

The trend of the year-on-year development of the number of passengers in regular air transport at M. R. Stefanik Airport Bratislava for the period 2007-2017 is shown in Fig. 2. The biggest decline was recorded between 2008 and 2009 with the onset of the economic crisis. The greatest growth rate is between 2014 and 2015. The projected development of the total number of equipped passengers [13] at the Airport of M. R. Stefanik Bratislava was not fulfilled (see Table 2) this forecast is not responsible not even growth rate. Regarding regular air transport, its offer also decreased between 2007 and 2017.

\section{Research of demand for regular air transport and demand for long-distance bus transport}

In terms of examining the impact of developments in regular air transport on long-distance and international regular bus transport, it is important to assess the routing and the number of flights in selected destinations with bus lines. 
Table 3. Evolution of the number of departures from Bratislava and Kosice airports to destinations served by regular bus transport for 2008 and 2018 (September), Source: authors based on data from [14]

\begin{tabular}{|c|c|c|c|c|c|c|c|c|c|c|}
\hline \multicolumn{2}{|c|}{ From/Departure } & \multicolumn{2}{|r|}{ To/Arrival } & \multicolumn{3}{|c|}{2008} & \multicolumn{3}{|c|}{2018} & Increase/decrease \\
\hline State & Departure City & State & Arrival City & Airline & $\begin{array}{c}\begin{array}{c}\text { Number of } \\
\text { departures/ } \\
\text { week }\end{array} \\
\end{array}$ & Travel time & Airline & $\begin{array}{c}\text { Number of } \\
\text { departures/ } \\
\text { week }\end{array}$ & Travel time & \\
\hline SK & Bratislava & $\mathrm{CZ}$ & Prague & ČSA & 26 & 01:00-01:05 & ČSA & 6 & $1: 00$ & \\
\hline SK & Kosice & $\mathrm{CZ}$ & Prague & ČSA & 24 & 01:30-01:35 & ČSA & 12 & $1: 30$ & \\
\hline SK & Kosice & $\mathrm{CZ}$ & Prague & SKY Europe & 8 & 1:15 & - & - & - & \\
\hline \multicolumn{4}{|c|}{ Absolutely number of departures by week SK - Prague } & \multicolumn{3}{|c|}{58} & \multicolumn{3}{|c|}{18} & $-68,97 \%$ \\
\hline SK & Bratislava & GB & London-Luton & SKY Europe & 19 & $02: 10-02: 20$ & WizzAir & 7 & $2: 15$ & \\
\hline SK & Bratislava & GB & London-Stansted & Ryanair & 14 & $2: 15$ & Ryanair & 12 & $02: 20-02: 25$ & \\
\hline SK & Kosice & GB & London-Luton & SKY Europe & 4 & $2: 35$ & WizzAir & 7 & $2: 50$ & \\
\hline SK & Poprad & GB & London-Luton & SKY Europe & 4 & $2: 35$ & WizzAir & 3 & $2: 35$ & \\
\hline \multicolumn{4}{|c|}{ Absolutely number of departures by week SK - London } & \multicolumn{3}{|c|}{41} & \multicolumn{3}{|c|}{29} & $-29,27 \%$ \\
\hline SK & Bratislava & $\mathrm{NL}$ & Eindhoven & - & - & - & Ryanair & 2 & $1: 45$ & \\
\hline SK & Bratislava & $\mathrm{BE}$ & Brusel & - & - & - & Ryanair & 4 & $1: 45$ & \\
\hline \multicolumn{4}{|c|}{ Absolutely number of departures by week SK - BENELUX } & \multicolumn{3}{|c|}{0} & \multicolumn{3}{|c|}{6} & $100,00 \%$ \\
\hline SK & Bratislava & $\mathrm{PL}$ & Warsaw & - & - & - & WizzAir & 3 & $1: 10$ & \\
\hline SK & Kosice & $\mathrm{PL}$ & Warsaw & - & - & - & LOT & 6 & 1:05 & \\
\hline \multicolumn{4}{|c|}{ Absolutely number of departures by week SK - PL } & \multicolumn{3}{|c|}{0} & \multicolumn{3}{|c|}{9} & $100,00 \%$ \\
\hline SK & Bratislava & IT & Milano & Ryanair & 7 & $1: 20$ & Ryanair & 5 & $1: 25$ & \\
\hline SK & Bratislava & IT & Roma & SKY Europe & 4 & $1: 40$ & Ryanair & 3 & $1: 40$ & \\
\hline SK & Bratislava & IT & Bologna & - & - & - & Ryanair & 2 & $1: 25$ & \\
\hline SK & Bratislava & IT & Olbia & - & - & - & Ryanair & 2 & $1: 55$ & \\
\hline \multicolumn{4}{|c|}{ Absolutely number of departures by week SK - IT } & \multicolumn{3}{|c|}{11} & \multicolumn{3}{|c|}{12} & $9,09 \%$ \\
\hline SK & Kosice & AT & Wien & Austrian & 12 & $1: 05$ & Austrian & 12 & 01:00-01:05 & \\
\hline \multicolumn{4}{|c|}{ Absolutely number of departures by week SK - AT } & \multicolumn{3}{|c|}{12} & \multicolumn{3}{|c|}{12} & $0,00 \%$ \\
\hline \multicolumn{4}{|c|}{ Absolutely number of departures from SK by week } & \multicolumn{3}{|c|}{122} & \multicolumn{3}{|c|}{86} & $-29,51 \%$ \\
\hline
\end{tabular}

The development of the number of departures from Bratislava and Kosice airports to destinations served by regular bus transport for 2008 and 2018 shows reduction in the offer about $29.51 \%$. The largest decrease is in the offer of regular air transport to the Czech Republic up to $68.97 \%$. The second largest decrease is for airlines in England (London), where compared to 41 flights there are only 29 flights, which is a decrease of $29.27 \%$. A new regular air service is from the Slovak Republic to Belgium and the Netherlands. A slight increase is in the number of flights to Italy about $9,09 \%$.

From the point of view of the demand for air transport, the price factor is a very important factor, all students have identified it as the most important factor. The second most important factor when selecting a ticket was the flight timetable (s). Also, the possibility of direct flight without transfer plays an important role in deciding on the choice of air transport. The passengers are willing to pay for a direct flight, if they have such a possibility. This was a specific survey of college students on the subject of traveling to the US [7-8].

The issue of demand elasticity as a result of increasing / reducing prices in mass passenger transport is a very important theme [15]. Therefore, also in the field of review of the impact of regular air transport on long-distance or international regular bus transport we compared minimum prices in selected destinations.

Table 4. Comparison of minimum prices for air and bus transportation in selected destinations; Source: authors based on data from [16-21]

\begin{tabular}{|c|c|c|c|c|c|c|c|c|c|c|}
\hline \multicolumn{4}{|c|}{ Transport session } & \multicolumn{6}{|c|}{ Price II. 09/2018 } & \multirow{3}{*}{$\begin{array}{c}\text { Difference between the } \\
\text { minimum prices for air and } \\
\text { bus transport }\end{array}$} \\
\hline \multirow{2}{*}{ State } & \multirow{2}{*}{ City } & \multirow{2}{*}{ State } & \multirow{2}{*}{ City } & \multicolumn{3}{|c|}{ Bus } & \multicolumn{3}{|c|}{ Flight } & \\
\hline & & & & Min. & Max. & Range of prices & Min. & Max. & Range of prices & \\
\hline SK & Bratislava & $\mathrm{CZ}$ & Prague & $9,99 €$ & $19,99 €$ & $10,00 €$ & $73,27 €$ & $116,27 €$ & $43,00 €$ & $\overline{63,28 €}$ \\
\hline SK & Kosice & $\mathrm{CZ}$ & Prague & $14,99 €$ & $32,99 €$ & $18,00 €$ & $73,27 €$ & $352,27 €$ & $279,00 €$ & $58,28 €$ \\
\hline SK & Kosice & GB & London & $75,00 €$ & $85,00 €$ & $10,00 €$ & $40,00 €$ & $180,00 €$ & $140,00 €$ & $-35,00 €$ \\
\hline SK & Poprad & GB & London & $75,00 €$ & $85,00 €$ & $10,00 €$ & $38,49 €$ & $144,99 €$ & $106,50 €$ & $-36,51 €$ \\
\hline SK & Bratislava & GB & London & & & & $19,50 €$ & $171,50 €$ & $152,00 €$ & - \\
\hline SK & Bratislava & $\mathrm{NL}$ & Eindhoven & $84,00 €$ & $84,00 €$ & $0,00 €$ & $33,50 €$ & $105,50 €$ & $72,00 €$ & $-50,50 €$ \\
\hline SK & Bratislava & $\mathrm{BE}$ & Brussels & $49,99 €$ & $84,00 €$ & $34,01 €$ & $19,50 €$ & $250,50 €$ & $231,00 €$ & $-30,49 €$ \\
\hline SK & Kosice & $\mathrm{PL}$ & Warsaw & $13,90 €$ & $19,90 €$ & $6,00 €$ & $166,27 €$ & $258,27 €$ & $92,00 €$ & $152,37 €$ \\
\hline SK & Bratislava & PL & Warsaw & & & & $28,50 €$ & $56,50 €$ & $28,00 €$ & - \\
\hline SK & Bratislava & IT & Milan & $39,99 €$ & $45,99 €$ & $6,00 €$ & $16,50 €$ & $152,50 €$ & $136,00 €$ & $-23,49 €$ \\
\hline SK & Kosice & AT & Vienna & $18,99 €$ & $28,00 €$ & $9,01 €$ & $122,27 €$ & $431,27 €$ & $309,00 €$ & $103,28 €$ \\
\hline Average & - & - & - & - & - & $11,45 €$ & - & - & $144,41 €$ & $22,36 €$ \\
\hline
\end{tabular}


From the point of view of prices, the bus transport is becoming more advantageous for destination to the Bratislava / Kosice - Prague and also for the destination Kosice - Vienna and Kosice - Warsaw. For the other compared destinations, air travel is even more advantageous in terms of cheapest airfares and not only travel time. These are the following destinations: Kosice / Poprad / Bratislava - London and also destinations BratislavaBrussels / Eindhoven / Milano. A comparison of minimum prices for bus and air transport is shown in Fig.3.

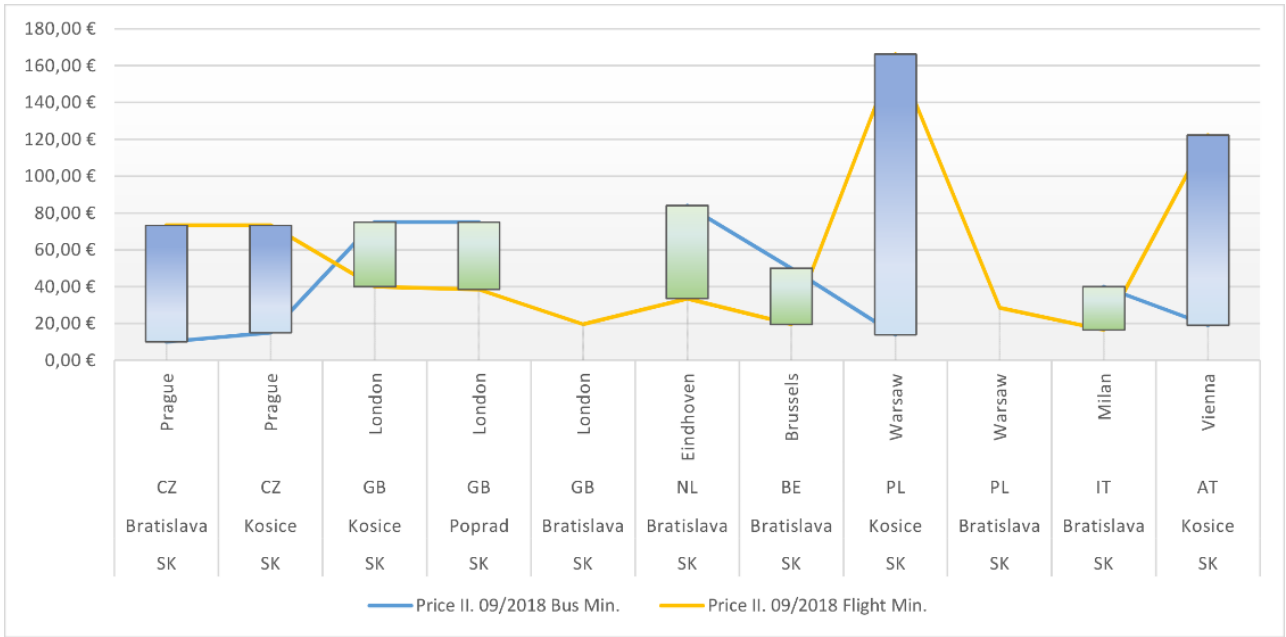

Fig. 3 Comparison of minimum prices for air and bus transportation in selected destinations; Source: authors based on data from $[18,19]$

From tab. 4 and Fig. 3 shows that the competitiveness of air transport also increases in terms of price policy, especially at the price of tickets, which are purchased well in advance of the date of transport. Due to load bus transport external costs, pressure to increase the wage of drivers, requirements for paying minimum wages in the start state or end of transport etc. there is a prerequisite for a significant increase in costs and thus prices in bus transport [20].

Another important determinant of traffic decision is the total time of transfer ,from house to house" [21]. For example, bus travel time from Kosice to Prague ranges from 10 hours to 12.5 hours the flight time is 1 hour and 30 minutes. This factor could no longer be included in the contribution in terms of the scope of the contribution.

\section{Conclusion}

In examining the impact of the development of regular air transport from the Slovak Republic on regular bus transport between 2008 and 2018, we found that in both modes of transport there was a decrease in the number of lines to destinations served by bus transport as well. In regular air transport, the drop is $29.27 \%$ and in bus transport by $33.33 \%$. The comparison base is 2008 with the year when the economic crisis began (in September) and ended the boom. In 2008, they were equipped with regular air transport from M. R. Stefanik Airport, the maximum number of passengers was up to 1.75 million, which has so far failed to overcome. In 2018 there are regular air lines operated only from three Slovak airports, except for Bratislava it is still from Kosice and Poprad. It is obvious that a large part of the population of the Slovak Republic uses regular flights from neighbouring countries mainly from the airports of Vienna, Budapest, Katowice and Krakow, which may 
also affect the drop in international bus lines. The offer of rail transport and its development was not taken into account in the examination. Here, it is worthwhile to compare the destination of Kosice-Prague or Bratislava-Prague. Particularly, private company RegioJet has established a bus service for these destinations and they are currently strengthening rail transport and busting bus transport. From the point of view of further research and refinement of the results, it would be necessary to refine the offer in air and bus transport on the number of passenger seats due to the different capacity of aircraft and buses.

It would also be appropriate to examine how the development of Gross Domestic Product (GDP) and Demand will also be affected or performance in regular air transport and long-distance, international bus transport. In view of the fact that the number of passengers cleared at the Bratislava airport at the time of the economic crisis 2009-2014 decreased.

The issue of elasticity of demand depends on the prices on the lines into to the same destinations in the air and bus transport or rail transport is another independent research theme in the field of transport services. Passenger decision making or choosing air or bus transport may depend from different psychological factors, safety, the possibility of using integrated transport systems for transportation to the airports etc. [22]. Of course, the issue of digital marketing and real-time sales of tickets also plays a role in deciding on the choice of mode of transport [23]. Some airlines from the Slovak Republic have the task of transporting part of the passengers to major international airports where these passengers continue with other airlines to other destinations often outside Europe. It would be necessary to focus on examining the final destination of passengers.

The paper did not exhaust all aspects of the issue but pointed out certain aspects of the development over the period considered.

\section{References}

1. J. Gnap, V. Konecny, P. Varjan, Nase more 65, 1, pp. 32-39 (2018), DOI: 10.17818/NM/2018/1.5

2. P. Varjan, D. Rovnanikova, J. Gnap, Conference: 12 th International Scientific Conference of Young Scientists od Sustainable, Modern and Safe Transport, 192, pp. 911-916 (2017), DOI: 10.1016/j.proeng.2017.06.157

3. J. Gnap, V. Konecny, M. Poliak, Ekonomicky casopis, 53, 7, pp. 668-684 (2006)

4. T. Skrúcaný, M. Kendra, B. Sarkan, J. Gnap; TOOLS OF TRANSPORT TELEMATICS, 531, pp.151-160 (2015), DOI: 10.1007/978-3-319-24577-5_15

5. T. Skrúcaný, J. Gnap, Conference: 14 th Transport Systems Telematics Conference (TST), 471, pp. 263-272 (2014)

6. V. Konečný, J. Gnap, I. Simková, Transport and telecommunication, 17, 1, pp. 28-39 (2016)

7. M. Grančay, Economic Review, 39, 4, pp. 524-538 (2010)

8. M. Grančay, Ekonomické rozhl'ady/Economic Review, 41, 2, pp. 234-247 (2012)

9. A. Tomova, Martisova, 8TH International Scientific Conference Business and Management 2014 (2014), DOI: 10.3846/bm.2014.072

10. Správa o súčasnom stave a koncepcia rozvoja Letiska M. R. Štefánika Bratislava vrátane jeho finančného krytia, Bratislava; <https://www.nrsr.sk/web/dynamic/ Download.aspx?DocID=329910 $>$ (22.9.2018)

11. M. Poliak, V. Konecny, Ekonomický časopis 7, 56, pp. $712-731$ (2008) 
12. J. Gnap, D. Rovňaníková, R. Rakovanová, E. B. Dvoryadkina. LOGI - Scientific Journal on Transposrt and Logistics, 8, 1, pp.28-37 (2017), DOI: 10.1515/logi-20170004

13. V. Konečný, J. Gnap, I. Šimková. Transport and Telecommunication, 17, 1, pp. 28-39 (2016), DOI: 10.1515/ttj-2016-0004.

14. J. Gnap, A. Kalašová, M. Gogola, J. Ondruš. Communications, 12, 3A, pp 116-120 (2010), ISSN 1335-4205

15. M. Poliak, V. Konecny, Ekonomický časopis, 56, 7, pp. 712-731 (2008)

16. R. Berežný, V. Konečný, Procedia Engineering, 192 (2017)

17. Analýza súčasného stavu účasti regiónov na správe letísk a návrh efektívnejšieho riešenia; Rokovanie vlády SR; www.rokovanie.sk/File.aspx/Index/Mater-Dokum181770

18. Štatistické údaje, Počet odbavených cestujúcich 2007-2017, bts.aero Bratislava Airport; https://www.bts.aero/o-letisku/o-spolocnosti/profil-spolocnosti/statisticke-udaje/ (23.9.2018)

19. https://amsbus.sk/

20. L. Bartuska, V. Biba, R. Kampf. Proceedings of the Third International Conference on Traffic and Transport Engineering (Scientific Research Center Ltd. Belgrade, 2016)

21. J. Lizbetin, M. Hlatka, L. Bartuska. Sustainability (Switzerland), 10, 9. (2018)

22. http://www.slovak-airports.net/i_bts.php?page=dest_tab

23. O. Stopka, M. Chovancova, R. Kampf, 18 th Internationl Scientific Conference - LOGI 2017, 134, Article Number: 00055, DOI: 10.1051/matecconf/201713400055 